\title{
GERAKAN SELF CONTROL PENYAKIT DEGENERATIF DI DESA GONDANG LOMBOK UTARA
}

\author{
Candra Dwipayana Hamdin ${ }^{1 *}$ dan Handa Muliasari ${ }^{1}$ \\ ${ }^{1}$ Program Studi Farmasi, Fakultas Kedokteran, Universitas Mataram \\ *Email: candradwipayana@unram.ac.id
}

\begin{abstract}
ABSTRAK. Penyakit degeneratif merupakan penyakit yang disebabkan oleh menurunnya kemampuan sel dibandingkan normal akibat penambahan usia. Kondisi degeneratif dipercepat oleh banyak faktor, salah satunya yang bisa dikendalikan adalah gaya hidup. Penyakit degeneratif merupakan penyebab kematian terbesar di dunia dikarenakan penderita baru menyadari setelah terjadi komplikasi. Hal tersebut karena penyakit degeneratif gejalanya tidak terlihat jelas sehingga sering disebut The Silent Killer. Guna meningkatkan kesadaran masyarakat terhadap penyakit degenerative, maka penting untuk dilakukan edukasi kepada masyarakat terkait bagaimana pencegahan, tanda dan gejala serta bagaimana perawatannya. Pengabdian ini bertujuan untuk memberikan pemahaman kepada masyarakat terkait penyakit degeneratif dan membentuk kelompok masyarakat sebagai agen edukator. Pengabdian masyarakat dilaksanakan di Dusun Karang Kates, Desa Gondang dengan jumlah 40 peserta. Dari hasil pretest ditunjukkan dengan hasil jawaban benar $50 \%$ dari keseluruhan menunjukkan kurangnya pengetahuan masyarakat terkait penyakit degeneratif. Setelah kegiatan diskusi dilakukan postest sebagai tolak ukur daya tangkap peserta. Hasil postest menunjukkan peningkatan pengetahuan dan wawasan terkait penyakit degeratif yaitu $95 \%$ jawaban benar. Selain itu telah terbentuk kelompok yang berkomitment sebagai agen edukator dari, oleh dan untuk masyarakat. Dalam jangka panjang diharapkan menjadi Pusat Edukasi Kesehatan Masyarakat.
\end{abstract}

Kata Kunci: pencegahan, perawatan, degeneratif, Desa Gondang, Lombok Utara.

ABSTRACT. Degenerative disease is a disease caused by decreased ability of cells compared to normal due to age. Degenerative conditions are accelerated by many factors, one of which can be controlled is lifestyle. Degenerative disease is the biggest cause of death in the world because the sufferer has only just realized after complications occur. This is because the degenerative disease symptoms are not clearly visible, called The Silent Killer. In order to increase public awareness of degenerative diseases, it is important to educate the society about how to prevent, signs and symptoms and how to treat them. This service aims to provide understanding to the community regarding degenerative diseases and form community groups as educators. Community service was successfully carried out in Karang Kates, Gondang Village, North Lombok with 40 participants. From the pretest results indicated by the results of the correct answer $50 \%$ of the total shows the level of public knowledge related to degenerative diseases. After the discussion, the posttest was conducted as a measure of the participants' understanding. The post-test results showed an increase in knowledge and insights related to degenerative diseases, namely 95\% correct answers. A group that has been committed as educator agen has been formed, by and for the community them self. In the long term, it is expected to become a Public Health Education Center.

Keywords: degenerative diseases, prevention, treatment, Gondang Village, North Lombok 


\section{PENDAHULUAN}

Penyakit degeneratif adalah penyakit akibat penurunan fungsi organ tubuh. Tubuh mengalami defisiensi produksi enzim dan hormon, imunodefisiensi, peroksida lipid, kerusakan sel (DNA) dan pembuluh darah. Secara umum dikatakan bahwa penyakit ini merupakan proses penurunan fungsi organ tubuh yang umumnya terjadi pada usia tua. Namun ada kalanya juga terjadi pada usia muda, akibat yang ditimbulkan adalah penurunan derajat kesehatan yang biasanya diikuti dengan penyakit (Saez, 2016).

Penyakit degeneratif disebut juga sebagai penyakit yang mengiringi proses penuaan. Pesatnya perkembangan penyakit tersebut telah mendorong masyarakat luas untuk memahami dampak yang ditimbulkannya. Menurut WHO, hingga akhir tahun 2014 saja penyakit degeneratif telah menyebabkan kematian hampir 15 juta orang di seluruh dunia. Penyakit degeneratif adalah istilah medis untuk menjelaskan suatu penyakit yang muncul akibat proses kemunduran fungsi sel tubuh dari keadaan normal menjadi lebih buruk. Terdapat sekitar 50 penyakit degeneratif. Penyakit yang masuk dalam kelompok ini antara lain kanker, diabetes melitus, stroke, jantung koroner, kardiovaskular, obesitas, dislipidemia dan sebagainya. Dari berbagai hasil penelitian modern diketahui bahwa munculnya penyakit degeneratif mempunyai kaitan cukup kuat dengan bertambahnya proses penuaan usia seseorang. Meskipun faktor keturunan juga berperan cukup besar (WHO, 2014).

Akhir-akhir ini insidensi penyakit degeneratif meningkat jumlahnya. Hal ini tidak terlepas dari perubahan pola hidup dan makin tingginya usia harapan hidup masyarakat. Pola hidup dengan diet tinggi lemak (makanan cepat saji) dan tingkat stressor tinggi mempunyai kontribusi positif terhadap timbulnya penyakit degeneratif. Terdapat korelasi yang positif juga antara umur dengan munculnya penyakit degeneratif (Sardiello, 2016).

Hal paling penting dalam menurunkan resiko terkena penyakit degeneratif adalah dengan pola/gaya hidup yang sehat. Gaya hidup ini termasuk pola diet yang seimbang dan sikap hidup yang tidak mudah stress. Diet yang banyak mengandung antioksidan akan mengurangi resiko terkena penyakit degeberatif (Sardiello, 2016)..

Makanan yang banyak mengandung vitamin A, E, C dan beta karoten. Vitamin A dapat bereaksi dengan radikal bebas melalui struktur ikatan rangkapnya. Vitamin $\mathrm{E}$ akan berikat dengan lipoprotein sehingga oksidasi lipoprotein akan terhambat. Hal ini akan mengurangi resiko terjadinya atherosklerosis. Vitamin $\mathrm{C}$ merupakan vitamin yang tidak dapat disintesis tubuh. Sehingga intake vitamin $\mathrm{C}$ dari luar sangat penting. Menguragi strees akan mengurangi paparan radikal bebas. Gaya hidup yang tenang, kalem, proporsional, tidak ambisius dalam akan meminimalkan resiko terkena penyakit degeneratif (Filaire et al, 2013)

Di Lombok Utara fasilitas kesehatan seperti Rumah Sakit sangatlah terbatas jumlahnya, yaitu hanya terdapat di Ibu Kota Kabupaten saja. Sehingga jangkauan informasi kesehatan hampir tidak bisa menyentuh masyarakat pedesaan. Mengingat penyakit degeneratif ini merupakan penyakit yang sering tidak di sadari oleh penderitanya sehingga disebut silent killer. Oleh karena itu perlu ada edukasi kepada masyarakat terkait bagaimana mencegah, mengetahui tanda dan gejala, cara pengatasan bahkan cara perawatan atau self-control.

Disebabkan alasan di atas maka dilaksanakan pengabdian kepada masyarakat dengan judul gerakan self-contro/ terhadap penyakit degeneratif di Desa Gondang Lombok Utara. Pengabdian ini bertujuan untuk memberikan edukasi kepada masyarakat terkait penyakit degeneratif. Dalam pelaksananaannya edukasi penyakit degeneratif dikombinasi dengan penyampaian materi 
DAGUSIBU untuk memberikan edukasi cara mendapatkan, menggunakan, menyimpan, dan membuang obat dengan benar.

\section{ANALISIS PERMASALAHAN}

Fasilitas kesehatan seperti Rumah Sakit sangatlah terbatas jumlahnya Di Lombok Utara, yaitu hanya terdapat di lbu Kota Kabupaten saja. Sehingga jangkauan informasi kesehatan hampir tidak bisa menyentuh masyarakat pedesaan. Mengingat penyakit degeneratif ini merupakan penyakit yang sering tidak disadari oleh penderitanya sehingga disebut silent killer. Oleh karena itu perlu ada edukasi kepada masyarakat terkait bagaimana mencegah, mengetahui tanda dan gejala, cara pengatasan bahkan cara perawatan atau self-control.

\section{SOLUSI YANG DITAWARKAN}

Melihat kejadian penyakit degeneratif yang semakin meningkat maka diperlukan peningkatan kesadaran masyarakat akan penyakit ini. Kurangnya kesadaran masyarakat disebabkan oleh kurangnya pengetahuan masyarakat mengenai penyakit ini. Oleh karena itu diperlukan edukasi kepada masyarakat, lebih jauh dibutuhkan sebuah pergerakan dari masyarakat untuk masyarakat. Pengabdian ini dilaksanakan dengan metode kelas dengan teknik penyampaian materi dalam bentuk diskusi dan permainan. Hal ini dirasa cocok untuk menarik antisias peserta. Selain itu materi yang disampaikan sebagian dituangkan dalam sebuah jargon misalnya DAGUSIBU yang merupakan singkatan DApatkan, GUnakan, SImpan, BUang obat dengan cara yang benar. Tidak hanya itu pada akhir acara dilakukan pembentukan kelompok yang berkomitmen sebagai agen edukator sesama masyarakat dalam tiap pertemuan bulanan.

\section{HASIL DAN PEMBAHASAN}

Edukasi self-control penyakit degeneratif ini disampaikan kepada sekelompok masyarakat di Dusun Karang Kates, Desa Gondang. Edukasi dilakukan melalui metode diskusi dan permainan. Dimulai dengan permainan yang bertujuan untuk mengetahui pemahaman awal yaitu dengan kuis. Peserta sangat antusias mengikuti kuis untuk mendapatkan hadiah yang telah disiapkan. Setelah mendapatkan gambaran pengetahuan awal masyarakat kemudian dilanjutkan dengan edukasi dan diskusi.

Setelah penyampaian materi kembali dilajutkan dengan permainan "siapa cepat dia dapat". Sebuah permainan yang dirancang untuk mengevaluasi pemahaman setelah edukasi dilakukan. Pada tahapan ini peserta sangat antusias untuk mendapatkan reward berupa bingkisan yang telah disiapkan. Setelah penyampaian materi, diskusi dan permaianan selesai dilanjutkan dengan pembentukan kelompok gerakan yang berkomitmen untuk melakukan gerakan pencegahan dan mengedukasi masyarakat pada forum diskusi masyarakat. Pemantauan secara berkelanjutan akan tetap dilakukan hingga kelompok penggerak bisa berjalan mandiri.

Hasil yang didapat dari kegiatan pengabdian ini adalah masyarakat mendapatkan pengetahui mengenai tanda dan gejala, pencegahan, perawatan penyekait degeratif khususnya diabetes. Selain itu pengetahui dasar mengenai pengelolaan obat di rumah melalui DAGUSIBU telah dipahami oleh masyarakat. Pada akhirnya terbentuk kelompok masyarakat yang berkomitmen sebagai agen edukator terkait Penyakit Degeneratif dan DAGUSIBU.

Diharapakan dengan adanya kelompok masyarakat ini dapat meningkatkan kesadaran masyarakat terkait penyakit degeneratif sehingga pada akhirnya mampu menguragi kejadian penyakit degeratif. Selain itu DAGUSIBU diharapkan mampu menjadi slogan yang mudah untuk diingat masyarakat terkait cara pengelolaan obat di rumah. 


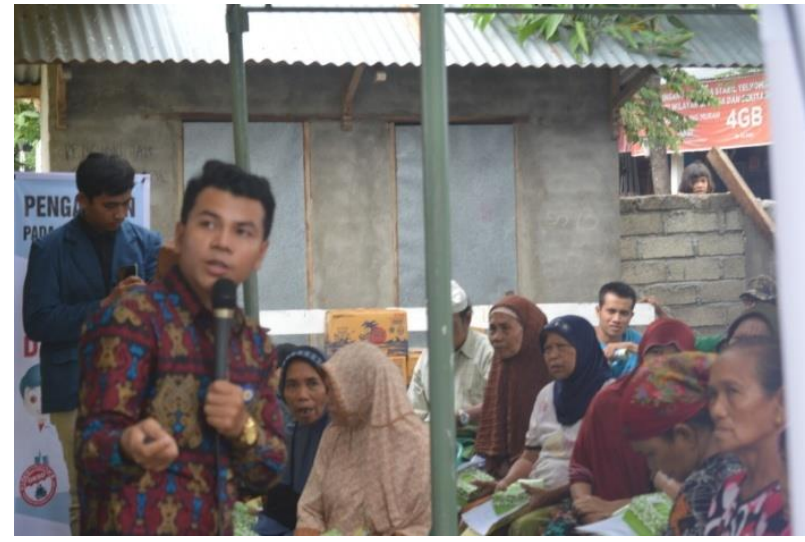

(a)

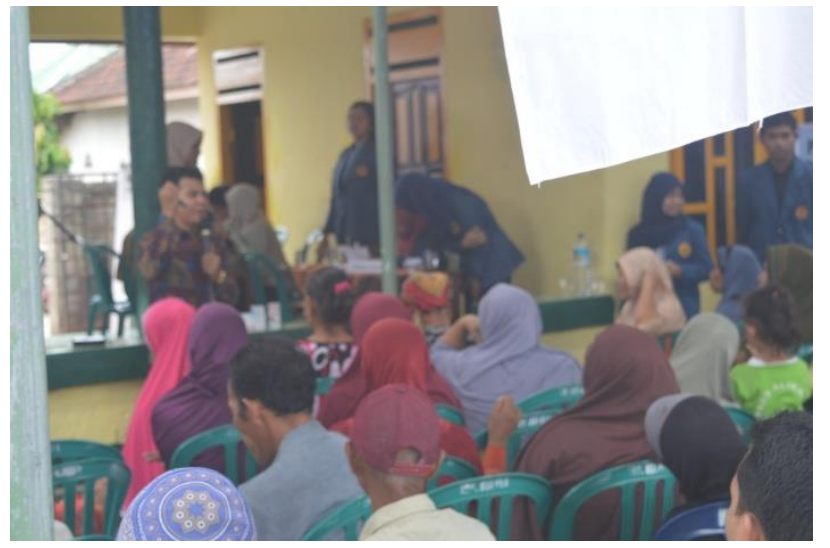

(b)

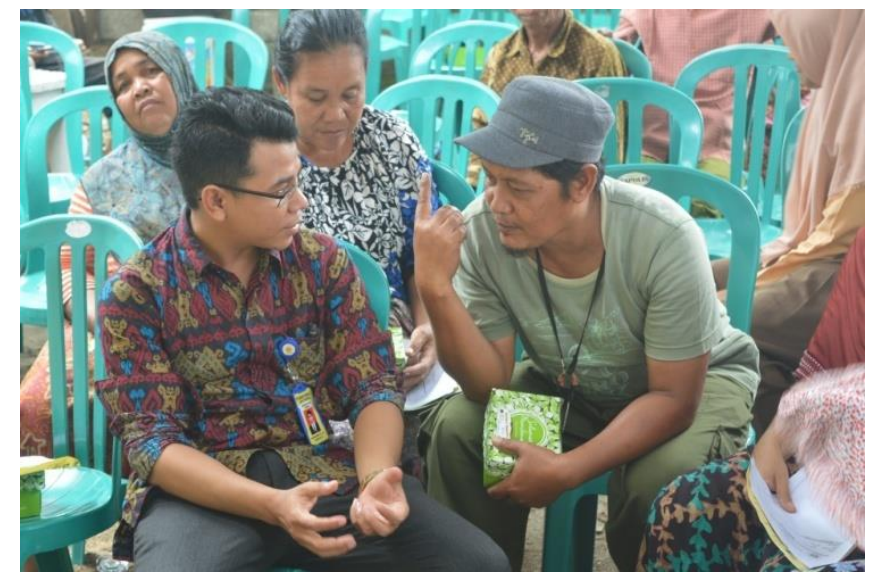

(c)

Gambar 1. Pelaksanaan Kegiatan Pengabdian Kepada Masyarakat (a) dan (b) Penyampaian materi dan diikuti diskusi; (c) diskusi dengan warga

Pengabdian ini dikemas dalam kelas sederhana dengan metode penyampaian materi melalui pretest, diskusi dan postest. Pretest dan postest dirancang dalam bentuk permainan dan kuis sehingga menarik antusiasme masyarakat. Diskusi berlangsung dua arah, mulai dari melempar statement tapi fakta yang terjadi kemudian peserta memberikan pendapat, begitu sebaliknya pertanyaan dari peserta kemudian didiskusikan dan diberikan arahan jawaban.

Dari hasil pretest dapat dikatakan masyarakat belum memilki pengetahun yang cukup terkai penyakit degeneratif (jenis, gejala, pencegahan, dan perawatannnya) ditunjukkan dengan hasil jawaban benar 50\% dari keseluruhan. Setelah dilakukan diskusi dilakukan postest sebagai tolak ukur daya tangkap peserta. Hasil postest menunjukkan peningkatan pengetahuan dan wawasan terkait penyakit degeratif yaitu $95 \%$ jawaban benar. Jumlah peserta yang hadri adalah 40 orang dari berbagai kalangan usia.

Lebih jauh dibutuhkan pengabdian lanjutan untuk memastikan kelompok edukator yang terbentuk siap secara personal sebagai agen edukator masyarakat. Hal yang perlu dilakukan adalah pertemuan rutin membahas kasus yang terjadi, teknik diskusi, sehingga agen edukator yang dibentuk memiliki pengalaman terkini terkait penyakit degeneratif. Lebih jauh kolompok ini diharapakan bisa menjadi pusat edukasi kesehatan masyarakat. Selain itu dengan adanya 
DAGUSIBU maka jangka panjang akan meningkatkan pemahaman masyarakat terkait bagaimana mengelola obat sehingga mampu menurunakan angka penyalahgunaan obat.

\section{KESIMPULAN}

Berdasarkan pengabdian yang telah dilakukan dapat disimpulkan pengetahuan masyarakat masih kurang terkait peyakit degeneratif teruatama di Dusun Karang Kates, Desa Gondang, Lombok Utara. Kondisi tersebut mengakibatkan masyarakat seolah - olah tidak peduli tehadap penyakit degeneratif.

Kegiatan pengabdian yang telah dilakukan ini merupakan tahap awal meningkatkan kesadaran masyarakat peduli terhdap penyakit degeneratif guna melakukan pencegahan terhadap penyakit yang disebut the silent killer.

Diperlukan pengabdian lanjutan untuk mendukung kelompok masyarakat atau yang disebut agen edukator, sehingga mampu berjalan mandiri. Dengan demikian kesadaran yang dibangun dari, oleh dan untuk masyarakat akan mampu mengurangi kejadian dan melakukan perawatan penyakit degeneratif.

\section{UCAPAN TERIMA KASIH}

Ucapan terima kasih diberikan kepada Kelompok Masyarakat Dusun Karang Kates, Desa Gondang, Lombok Utara, dan LPPM Universitas Mataram.

\section{REFERENSI}

G. T. Sáez, "DNA Damage and Repair in Degeberatif Diseases 2016," Int. J. Mol. Sci., vol. 18, no. 1, 162017.

"WHO | Global status report on noncommunicable diseases 2014," WHO. [Online]. Available: http://www.who.int/nmh/publications/ncdstatus-report-2014/en/. [Accessed: 14-Nov-2018].

M. Sardiello, "Transcription factor EB: from master coordinator of lysosomal pathways to candidate therapeutic target in degeberatif storage diseases," Ann. N. Y. Acad. Sci., vol. 1371, no. 1, pp. 3-14, 2016.

E. Filaire et al., "Lung cancer: what are the links with oxidative stress, physical activity and nutrition," Lung Cancer Amst. Neth., vol. 82, no. 3, pp. 383-389, Dec. 2013. 